\title{
Quantitative Ethnobotanical Study, Phytochemical Screening and Antibacterial Assay of Ethnomedicinal Plants of T'boli in Lemsnolon, Tboli, South Cotabato
}

\author{
Joni Rey H. Campilan ${ }^{1, a *}$, Marigold C. Tumamac ${ }^{1}$ and Emma L. Dorado ${ }^{2}$ \\ ${ }^{1}$ The Graduate School, Notre Dame of Marbel University, Koronadal City, South Cotabato \\ ${ }^{2}$ Natural Sciences and Mathematics Department, College of Arts and Sciences, Notre Dame of \\ Marbel University, City of Koronadal, Philippines \\ *projectjoni@gmail.com
}

Keywords: Tboli, ethnomedicinal plants, phytochemical screening, paper disc diffusion.

\begin{abstract}
Tbolis in Lemsnolon, Tboli, South Cotabato are one of the ethnic groups in the Philippines serving as repository of novel knowledge on ethnomedicine. On July 2014, a research was conducted among Tboli tribe in Lemsnolon to document the local knowledge on ethnomedicinal plants before environmental and cultural changes deplete the resources. Selected important ethnomedicinal plants were quantified through Relative Frequency Citation and Use Value. Selected important medicinal plants were screened for phytochemical constituents, and their antibacterial property was determined through paper disc diffusion method. A total of 28 medicinal plants belonging to 21 families were recorded, most are used for symptoms, signs and abnormal clinical and laboratory findings (13spp.) and certain infectious and parasitic diseases ( $5 \mathrm{spp}$.). The most abundant medicinal plant families were Asteraceae (5spp.) and Euphorbiaceae (3spp.), the most dominant life forms of the species includes herbs (17spp.) followed by shrubs (4spp.), the most frequently used part were leaves $(42 \%)$ followed by stems $(11 \%)$, the most common preparation method was decoction $(47 \%)$, the most common route of administration is through oral (66\%). Artemisia vulgaris, Bryophyllum pinnatum, Elephantopus sp., Emilia sonchifolia, Ficus pseudopalma, Hyptis capitata, and Leucaena glauca have the highest RFC (0.29), E. sonchifolia has the highest Use Value (0.71). Selected important ethnomedicinal plants, Artemisia vulgaris, Costus malorticanus, Elephantopus sp., Emilia sonchifolia and $H$. capitata, were found to be rich in alkaloids while free fatty acids, flavonoids, tannins and anthraquinones were present in most of these selected plants. However, ethanolic extracts of the selected important medicinal plants showed inactive zone of inhibition against $S$. aureus and E. coli. Results showed that plants used for healing among Tboli community in Lemsnolon are found to be possible sources of potential drugs and are subject for further phytochemical and pharmacological investigations.
\end{abstract}

\section{Introduction}

From the beginning, plants become as one of man's resources for living. These producers are highly utilized for healthcare. In fact, $80 \%$ of the entire world population depends on traditional medicine for primary healthcare needs [30]. Such that in the occurrence of different diseases, sophisticated scientists continue to intensify their quest for effective, yet affordable, therapeutic substances from the plant kingdom [23]. Ethnobotanical studies, phytochemical screening and antimicrobial assays serve as a baseline for the discovery of these potential medicinal plants.

Throughout Philippine archipelago, ethnobotanical studies are carried sporadically covering innate populations of ethnic and local inhabitants who considered ethnomedicinal plants as useful in healing various diseases [2]; [14]. Most of these are focused on well-known indigenous groups including Pinatubo Negritoes and their use of plant resources; the Tasadays in Mindanao, who have been subject to various studies; the Y'Apayaos of Cagayan and the Ibaloi of Benguet province and their utilization of forest resources [6]. These studies set a baseline information in which potential ethnomedicinal plants are discovered. Ethnomedicinal plants contain small quantities of secondary metabolites in different forms (phytochemicals) such as alkaloids, saponins, flavonoids, tannins, and anthraquinones which are potential for new drugs [34]; [29]. Even so, a considerable number of plants 
still needs to be scientifically validated and much work is still needed to investigate the bioactivity and phytochemicals of plants [24].

The Tboli term refers to the tribal group found in South Cotabato, specifically in the upper valley areas, while Tboli refers to one of the municipalities where this tribal group dwells. Tbolis are known for their rich cultural heritage such as Tnalak weaving and brass casting. Amidst development and urbanization, the tradition of healing using plants continue to exists among Tboli communities. It provides considerable information about the use of many plants or plant parts as medicine; however, it has been based mostly on empirical grounds. There is a need for scientific validation of such empirical knowledge making it necessary to understand the biological activity of plants and the presence of possible bioactive compounds to support their traditional medicinal use.

This study focuses in one of the 25 barangays of Tboli, South Cotabato called Lemsnolon which holds one of the communities of Tboli. Majority of the population of Lemsnolon are agriculturist. They grow banana, coconut, corn, pineapple, and rice, and they rear livestocks including cattles, chickens, goats, and pigs. Hill ranges covered with abundant flora and fauna in the expanse of the barangay serves as the source of innate traditional healing system of the rural community. For the purpose of their ailments tribal people rely upon medicinal plants made known to them by their elders. However, through time, the knowledge of traditional healing becomes focused on few numbers of the population and most of these practices are undocumented. This ethnobotanical study assists to document this knowledge and to help in the conservation of Tboli traditions.

\section{Objectives}

This study sought to:

1. Document the ethnomedicinal plants utilized by the Tboli in Lemsnolon, Tboli, South Cotabato;

2. Quantify the importance of the ethnomedicinal plants through Relative Frequency Citation (RFC) and Use Value (UV);

3. Determine the presence of secondary metabolites from the crude ethanolic extract of the selected important ethnomedicinal plants through phytochemical screening and;

4. Tests the antimicrobial activity of selected ethnomedicinal plants using paper disc diffusion method against Staphylococcus aureus, Escherichia coli, Candida albicans

\section{Methodology}

\section{A. Study Site}

Lemsnolon, Tboli, South Cotabato, Philippines is a small village serving as a home to Tbolis and Ilonggos. As of 2017, it has a population of 2,980 with a total land area of1355.91 hectares [28]. Fig. 1 shows the map of Lemsnolon. 


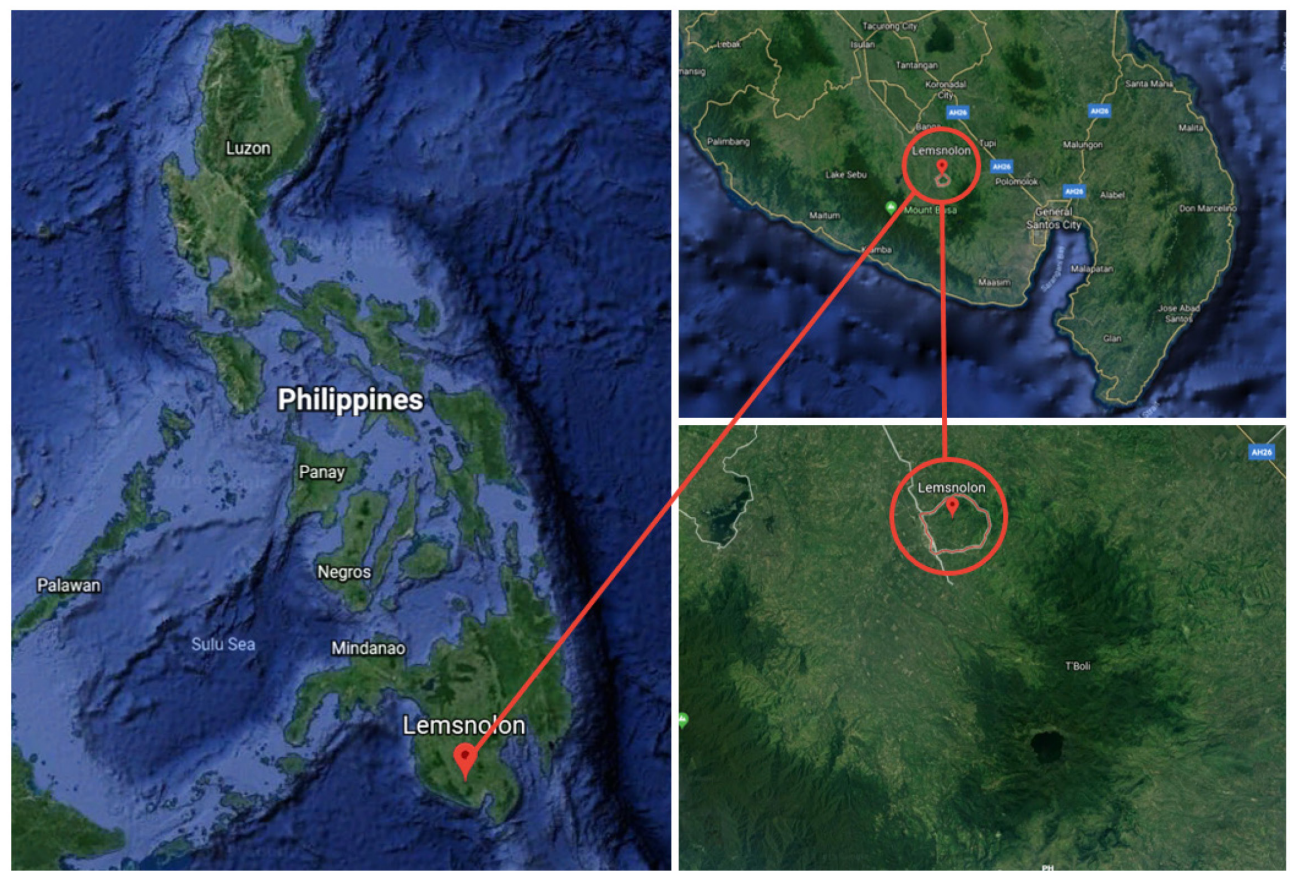

Figure 1. Map of the Philippines and the study area [41].

\section{B. Ethnomedicinal data collection}

This study followed the ISE Code of Ethics [38]. Research permit signed by the barangay captain was secured prior to gathering of data and specimens.

On survey date, July 10, 2014, the researchers met with the captain and officials in Lemsnolon to enlist names and addresses of tribal people locally known to have rich indigenous knowledge and have utilized plants for a long term before contacting them with the request for interviews. Interviews with the respondents begun after explaining the aims of the study.

A total of seven informants including 6 females and 1 male were interviewed. Informants were between the ages 40 to 89 years old, with an age mean of 63 years old. A survey instrument questionnaire adapted from Lagenberger et al. (2009) entitled "Information sheet on traditional herbal preparations and medicinal plants of Tboli" was designed to facilitate semi-structured face to face interviews accompanied by field walks in the area with the informants. The instrument is directed to record the medicinal plants' local name, scientific name, life form, locale, parts used, medicinal uses, mode of preparation, and mode of administration. The interviews were conducted in local language with the help of translators in the community to clearly communicate with the interviewees. Focus group discussions were conducted after the survey for verification of gathered data.

\section{Plant identification}

The study involved field work for the collection of voucher specimens of plants encountered with the exception of some very common cultivated plants which were identified in the field. Plant photographs were taken and plant samples useful for identification (flowers, fruits, roots, stem or twig with leaves) in addition to the parts used medicinally were collected, dried and compressed in newspapers. Medicinal plants were identified using plant guides and were finally identified by Prof. Leopoldo L. Remollo, a plant taxonomist.

\section{Quantitative ethnomedicinal data analysis}

All ethnomedicinal data from the semi-structured interview were encoded in the MS Excel 2013 Software and were summarized for descriptive statistics. Frequency of medicinal plants' (1) family, (2) form, (3) locale, (4) parts used, (5) mode of preparation, and (6) mode of administration were calculated. Plant medicinal applications were categorized using International Statistical Classification of Diseases and Related Health Problems (ICD-10) (2010) of World Health Organization. 


\section{Relative Frequency Citation}

The index of relative frequency citation (RFC) of the collected ethnomedicinal information was calculated as;

$$
R F C=\frac{F C}{N}(0<R F C<1)
$$

The index shows the local importance of each species and it is given by the frequency of citation where $F C$ is the number of informants mentioning the use of the species divided by the total number of informants participating in the survey $(N)$, without considering the use-categories (Vitalini et al, 2013).

\section{Use Value (UV)}

The Use Value (UV) indicates the species that are considered most important by a given population (Mathur \& Sundaramoorthy, 2013). It was calculated using the following formula;

$$
U V=\sum U i / N
$$

where $U i$ is the number of uses mentioned by each informant for a given species and $N$ is the total number of informants.

\section{E. Collection and extraction of plant materials}

Five abundant plants with the highest RFC and UV values were chosen for phytochemical screening and antibacterial assay excluding the common medicinal plants. Fresh mature plants materials were collected from Lemsnolon, Tboli, South Cotabato on July 2014 as pre-identified by informants who use them as herbal medicine. Five hundred grams fresh weight of Artemisia vulgaris (leaves), Costus malorticanus (stems), Elephantopus sp. (leaves), Emilia sonchifolia (leaves) and Hyptis capitate (leaves) were thrice washed in a running tap water to remove dirt from the samples. Then plants were cut into pieces and were grinded using an electric blender. Each sample was soaked in $500 \mathrm{~mL} 70 \%$ ethanol for 24 hours, filtered and concentrated under vacuum at $50^{\circ} \mathrm{C}$ using rotary evaporator. The crude ethanolic extract of the indigenous plants was then poured in covered glass bottles and stored in refrigerator until they were evaluated for their phytochemical content and antimicrobial activity.

\section{F. Phytochemical screening}

Screening procedures for alkaloids, saponins, free fatty acids, flavonoids, tannins, and anthraquinones were adapted from [1] and [12].

\section{Test for Alkaloids: Dragendorff's and Mayer's Reagent}

An equivalent of $15 \mathrm{~g}$ of plant extract was evaporated into a syrupy consistency over a steam bath. Then, $5 \mathrm{~mL}$ of $2 \mathrm{M} \mathrm{HCl}$ was added to the concentrated extract, heated and stirred for 5 minutes, and cooled to room temperature. $1 \mathrm{~mL}$ of the filtrate was added with 2 to 3 few drops of Dragendorff's reagent and another $1 \mathrm{~mL}$ of the filtrate was tested with 2 to 3 drops of Mayer's Reagent. The relative amount of precipitation was observed and scored as $(+)$ slight turbidity, $(++)$ definite turbidity, and $(+++)$ heavy precipitation as an indicator of the presence of alkaloids.

\subsection{Confirmatory Test: Primary, Secondary, or Tertiary Alkaloids}

A $3 \mathrm{~mL}$ portion of the crude extract was transferred to a test tube and was added with $28 \%$ ammonia solution until becomes alkaline to litmus paper. Extraction of the alkaline solution was made by adding small portions of less than $10 \mathrm{~mL}$ chloroform. The lower chloroform extract was collected and the upper aqueous layer will be reserved for the quarternary and/or amine oxide test. 
The chloroform extract was evaporated to dryness over a steam bath. $5 \mathrm{~mL}$ of $2 \mathrm{M} \mathrm{HCl}$ was added and stirred over a steam bath for 2 minutes and was allowed to cool. The solution was then filtered and filtrate was separated into two portions. One portion was tested with Mayer's reagent and the other with Dragendorff's reagent. The same indicators were used in observation of the precipitation in the solution, indicating the presence of primary, secondary, or tertiary alkaloids.

\subsection{Test for Quarternary Bases and/or Amine Oxide}

The alkaline upper aqueous layer obtained in the confirmatory test was acidified with $2 \mathrm{M} \mathrm{HCl}$. The solution was then filtered and the filtrate was divided into two portions. One portion was tested with Mayer's reagent and the other portion with Dragendorff's reagent. The result was observed and recorded as above.

\section{2. $\quad$ Froth Test for Saponins and Test for Free Fatty Acids}

An equivalent of $2 \mathrm{~g}$ ethanolic extract was transferred in a test tube. In another tube, $1 \mathrm{mLEntadaphaseoloides}$ (Linn.) (gogo) extract was added to serve as standard. Each test tube was diluted with $10 \mathrm{~mL}$ distilled water and was shaken vigorously for 30 seconds. Then, allowed to stand and was observed for 10 minutes. The sample is presumed to contain saponins if honeycomb froth height, greater than $2 \mathrm{~cm}$, persists above the liquid surface.

For plant extracts with poor frothing effects, 3 drops of 5\% sodium carbonate solution were added to basify the extract. The formation of a stable and dense froth indicate the presence of free fatty acids.

\section{Test for Flavonoids}

An equivalent of $5 \mathrm{~g}$ plant extract was allowed to evaporate in incipient dryness over a steam bath and was allowed to cool in room temperature. The residue was defatted with $9 \mathrm{~mL}$ petroleum ether. Petroleum ether was then discarded. The defatted aqueous layer was diluted with $10 \mathrm{~mL}$ of $80 \%$ ethyl alcohol, filtered and the filtrate was divided into three test tubes. One portion serves as the control.

\subsubsection{Test for Leucoanthocyanins: Bate-Smith and Metcalf Method}

One portion was treated with $0.5 \mathrm{~mL}$ concentrated $\mathrm{HCl}(12 \mathrm{M})$. A change in color of the solution was observed. Then the solution was warmed for 15 minutes in a water bath. Any further change in color was observed within an hour and was compared with the control. A strong red or violet color indicate the presence of leucoanthocynains.

\subsubsection{Test for y-benzopyrone nucleus: Wilstatter "cyanidin” test}

The other portion of the alcoholic filtrate was treated with $0.5 \mathrm{~mL}$ concentrated $\mathrm{HCl}(12 \mathrm{M}) .3$ to 4 pieces of magnesium strips were then added. Color change was observed within ten minutes as compared with the control tube. In observed definite coloration, an equal amount of water and $1 \mathrm{~mL}$ isopropyl alcohol was added. The mixture was shaken and allowed to stand. The color of each layer was noted. Colors ranging from orange to red, to crimson and magenta, and occasionally to green or blue indicate a positive result.

\section{Tests for Tannins: Gelatin and Ferric Chloride Tests}

Five grams of the ethanolic extract was evaporated to dryness on a steam bath. $20 \mathrm{~mL}$ of hot distilled water and 5 drops of $10 \%$ sodium chloride solution was then added to salt out undesirable constituents. The solution was mixed well with a stirring rod and filtered. The filtrate was divided into 3 test tubes. One test tube served as blank. An aqueous solution of tannic acid was used as a reference standard.

\subsection{Gelatin Test}

In another test tube, 3 drops gelatin-salt reagent was added. The same was done for the aqueous solution of tannic acid. The formation of any precipitate indicate the presence of tannins. 


\subsection{Ferric Chloride Test}

The third test tube was treated with 3 drops of ferric chloride solution. The same was done to the reference standard. A blue black color indicate the presence of hydrosylable tannins, and a brownish green color indicate the presence of condensed tannins.

\section{5. $\quad$ Test for Anthraquinones (Borntrager's Test)}

A portion of crude extract equivalent to $1 \mathrm{~g}$ of plant material was evaporated to incipient dryness over a water bath. The residue was taken up with $10 \mathrm{~mL}$ distilled water and filtered. The filtrate was treated twice with $5 \mathrm{~mL}$ portions of benzene. The benzene extract was divided into two portions. One portion served as control. The other portion was treated with $5 \mathrm{~mL}$ ammonia solution, shaken and compared with the control. Red coloration in the lower alkaline layer indicate the presence of anthraquinones.

\section{G. Paper Disc Diffusion Assay}

The ethanolic crude extracts from the selected important medicinal plants were tested for their inhibitory activity against representative test bacteria: (1) Gram-positive bacteria: Staphylococcus aureus, and (2) Gram-negative bacteria: Escherichia coli from NDMU Biology laboratory through paper disc diffusion assay. Bacterial cell suspended in broth was prepared from a 24-hour old culture, adjusted to $0.5 \mathrm{Mc}$ Farland standard, and swabbed on petri plates prefilled with 20mLMuellerHinton agar.6mm discs (Whatman) were impregnated with $10 \mu \mathrm{l}$ of $100 \% \mathrm{v} / \mathrm{v}$ and $50 \% \mathrm{v} / \mathrm{v}$ selected important medicinal plant ethanolic extracts. Positive control discs were impregnated with $10 \mu$ gGentamycin and Ampicillin. Discs with $10 \mu \mathrm{L}$ distilled water served as negative control and discs with $10 \mu \mathrm{L}$ ethanol served as solvent control. Discs were then introduced unto the upper layer of the seeded agar plates.

The assay was done aseptically in triplicates with three disks per plate following a randomized complete block design. Plates were then incubated in inverted position at $37^{\circ} \mathrm{C}$ for $24 \mathrm{hrs}$. Following incubation, zones of inhibition including paper discs were then measured to the nearest $\mathrm{mm}$ with an Orion ruler and recorded. Bioactivity was assessed using the following rating system: (1) very active, $>19 \mathrm{~mm}$ zone of inhibition; (2) active, 13-19 mm zone of inhibition; (3) partially active, 10-12mm zone of inhibition; and (4) inactive, $<10 \mathrm{~mm}$ zone of inhibition.

\section{Results and Discussion}

\section{Medicinal plant diversity, parts used and medicinal applications}

A total of 28 plant species belonging to 21 families were catalogued in Table 1, with traditional uses as herbal medicine against various diseases. The most abundant medicinal plant families were Asteraceae (5 reported species), Euphorbiaceae (3) and Asparagaceae (2) while the rest of the families were represented with 1 species. The reasons for the high degree of ethnomedicinal plants from Asteraceae could be deducted from the fact that Asteraceae is one of the largest and most diverse of all plant families where it includes over 1,600 genera and 23,000 individual species [15]; [14]. However, this result is different in comparison to other ethnobotanical studies in the Philippines [16]; [36] where Poaceae, Verbenaceae and Fabaceae dominate. The most dominant life forms were herbs (17) and shrubs (4) which could be related with the type of vegetation of the study area which is covered by bushland, grassland, woodland and secondary forests vegetation types. Thirty-seven percent of these plants are found in forests (15 species), 29\% in gardens (12), 24\% along roads (10) and $10 \%$ in farms (4). Our findings regarding the location of ethnomedicinal plants in the Philippines were in agreement with other ethnic-floras [2]; [14] that most plants are found in the wild. The presence of secondary forests surrounding the area suggests such result. 


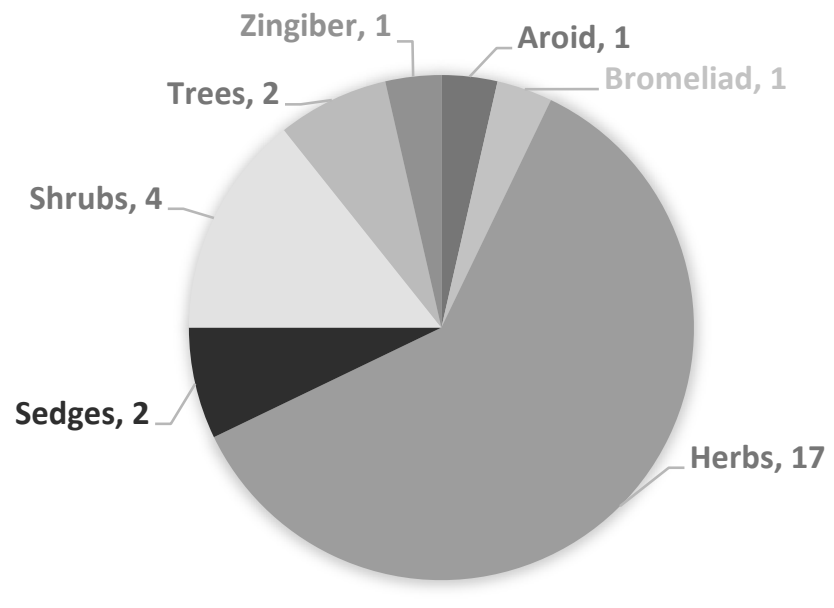

Figure 2. Life Forms of Ethnomedicinal Plants.

Leaves are the most utilized plant part (42\%) for medicinal application, followed by roots (31\%) and stems (11\%). This is also similar with other studies [2]; [36]. The ease of accessibility to leaves explains their frequent inclusion in most of the preparations [14], [36]. Using fruits, leaves, seeds, and stems which accounts for $61 \%$ leads to the conclusion that harvesting medicinal plants poses no significant threat to the natural vegetation of the study area compared to utilization of barks, roots, and whole plant that threat the survival of individual plants. Based on the plants' mode of preparation for medicinal use (as shown in Fig. 4), 14 spp. of these are decocted, 6 are poultice, 4 are juiced, 4 are pounded, and 2 are pretreated by applying mineral oil or gas prior to topical application. Decoction is one of the trends of preparation of ethnomedicinal plants here in the Philippines [2]; [16]; [14]. Decoctions do not provide standardized dosages and a lack of preservatives allows for microbial growth suggesting that these ethnomedicinal plants needs to be regulated. Most of the remedies are prepared from a single species; mixtures are used infrequently. $21 \mathrm{spp}$. or $66 \%$ of the plants are orally administered, $10 \mathrm{spp}$. or $31 \%$ are through topical application and $1 \mathrm{sp}$. or $3 \%$ is inhaled. Above mentioned authors also found out that drinking or in taking orally of ethnomedicines is the most common mode of administration.

Table 1. Ethnomedicinal application of plants of Tboli in Lemsnolon, Tboli, South Cotabato.

\begin{tabular}{|c|c|c|c|c|c|c|c|c|}
\hline Family & $\begin{array}{c}\text { Scientific } \\
\text { Name }\end{array}$ & $\begin{array}{l}\text { Local } \\
\text { Name }\end{array}$ & RFC & UV & $\begin{array}{l}\text { Parts Used/ } \\
\text { Formulation }\end{array}$ & $\begin{array}{c}\text { Medicinal } \\
\text { Applications }\end{array}$ & $\begin{array}{c}\text { ICD10 } \\
\text { Category }\end{array}$ & $\underset{\text { tion }}{\text { Administra- }}$ \\
\hline Araceae & $\begin{array}{l}\text { Homolomena } \\
\text { philippinensis } \\
\text { Engl. }\end{array}$ & Kuho & 0.14 & 0.14 & Root decoction & $\begin{array}{l}\text { Pregnancy } \\
\text { related } \\
\text { condition, } \\
\text { unspecified } \\
\text { (Bughat) }\end{array}$ & XV & Oral \\
\hline Asparagaceae & $\begin{array}{l}\text { Dracaena } \\
\text { reflexa }\end{array}$ & Kilay & 0.14 & 0.14 & $\begin{array}{l}\text { Root and leaves } \\
\text { decoction }\end{array}$ & $\begin{array}{l}\text { Swollen leg } \\
\text { during } \\
\text { pregnancy }\end{array}$ & XIII & Oral \\
\hline Asparagaceae & $\begin{array}{l}\text { Cordyline } \\
\text { fruticosa (L.) } \\
\text { A. Chev. }\end{array}$ & $\begin{array}{l}\text { Klangla } \\
\mathrm{n}\end{array}$ & 0.14 & 0.14 & Leaves poultice & Rashes & XVIII & Topical \\
\hline Asteraceae & $\begin{array}{l}\text { Elephantopus } \\
\text { spicatus Juss } \\
\text { ex Aubl. }\end{array}$ & $\begin{array}{l}\text { Tumom } \\
\text { bok }\end{array}$ & 0.14 & 0.14 & Root decoction & $\begin{array}{l}\text { Bloody } \\
\text { Diarrhea }\end{array}$ & I & Oral \\
\hline Asteraceae & $\begin{array}{l}\text { Artemisia } \\
\text { vulgaris Linn. }\end{array}$ & $\begin{array}{l}\text { Seketlag } \\
\text { isen }\end{array}$ & 0.29 & 0.14 & $\begin{array}{l}\text { Leaves poultice as } \\
\text { wrapped in } M u s a \\
\text { paradisiaca leaves } \\
\text { and juiced }\end{array}$ & Cough & XVIII & Oral \\
\hline \multirow{2}{*}{ Asteraceae } & \multirow{2}{*}{$\begin{array}{l}\text { Elephantopus } \\
\text { sp. }\end{array}$} & \multirow{2}{*}{$\begin{array}{l}\text { Bako } \\
\text { baling } \\
\text { or } \\
\text { tambako }\end{array}$} & \multirow{2}{*}{0.29} & \multirow{2}{*}{0.29} & Root decoction & Diarrhea & I & Oral \\
\hline & & & & & Leaf paste & Wound & XVIII & Topical \\
\hline
\end{tabular}


Table 1. Ethnomedicinal applications of plants of T'boli

in Lemsnolon, Tboli, SouthCotabato (continued).

\begin{tabular}{|c|c|c|c|c|c|c|c|c|}
\hline Family & $\begin{array}{l}\text { Scientific } \\
\text { Name }\end{array}$ & $\begin{array}{l}\text { Local } \\
\text { Name }\end{array}$ & RFC & $\mathbf{U V}$ & $\begin{array}{c}\text { Parts Used/ } \\
\text { Formulation }\end{array}$ & $\begin{array}{c}\text { Medicinal } \\
\text { Applications }\end{array}$ & $\begin{array}{c}\text { ICD10 } \\
\text { Category }\end{array}$ & $\begin{array}{c}\text { Administra- } \\
\text { tion }\end{array}$ \\
\hline Asteraceae & $\begin{array}{l}\text { Acmelia } \\
\text { grandiflora }\end{array}$ & $\begin{array}{l}\text { Yellow } \\
\text { dots }\end{array}$ & 0.14 & 0.14 & Root paste & Toothache & XI & Topical \\
\hline \multirow[t]{2}{*}{ Asteraceae } & \multirow[t]{2}{*}{$\begin{array}{l}\text { Emilia } \\
\text { sonchifolia } \\
\text { (Linn.) DC. }\end{array}$} & \multirow[t]{2}{*}{$\begin{array}{l}\text { Kloonm } \\
\text { ugol }\end{array}$} & \multirow[t]{2}{*}{0.29} & \multirow[t]{2}{*}{0.50} & $\begin{array}{l}\text { Boiled poulticed } \\
\text { leaves wrapped in } \\
\text { Colocasia esculenta } \\
\text { leaves }+ \text { Sugar } \\
\text { Cane worm }\end{array}$ & $\begin{array}{l}\text { Toothache, } \\
\text { Hypertension }\end{array}$ & XI, IX & Oral \\
\hline & & & & & Leaf paste & $\begin{array}{l}\text { Vomiting, } \\
\text { Fever, } \\
\text { Hypertension }\end{array}$ & XVIII, IX & Inhalation \\
\hline \multirow{2}{*}{ Balsaminaceae } & \multirow{2}{*}{$\begin{array}{l}\text { Impatiens } \\
\text { balsamina } \\
\text { Linn. }\end{array}$} & \multirow{2}{*}{$\begin{array}{l}\text { Sukot } \\
\text { lagembon }\end{array}$} & \multirow{2}{*}{0.14} & \multirow{2}{*}{0.29} & Leaves decoction & Fever & XVIII & Oral \\
\hline & & & & & Stem juice & Stuttering & IV & Oral \\
\hline Basellaceae & $\begin{array}{l}\text { Basella } \\
\text { alba } \mathrm{L} .\end{array}$ & Alugbati & 0.14 & 0.14 & Leaf juice & Boil & XIII & Oral \\
\hline Bromeliaceae & $\begin{array}{l}\text { Ananas } \\
\text { comusus }\end{array}$ & Pinya & 0.14 & 0.14 & Leaves decoction & Measles & I & Oral \\
\hline Caricaceae & $\begin{array}{l}\text { Carica } \\
\text { papaya }\end{array}$ & Tapaya & 0.14 & 0.14 & $\begin{array}{l}\text { Young fruit } \\
\text { poultice }\end{array}$ & Appendicitis & $\mathrm{XI}$ & Oral \\
\hline Costaceae & $\begin{array}{l}\text { Costus } \\
\text { malorticanus }\end{array}$ & Siwak & 0.14 & 0.14 & $\begin{array}{l}\text { Lower stem part or } \\
\text { fruit juice }\end{array}$ & Cough & XVIII & Oral \\
\hline Crassulaceae & $\begin{array}{l}\text { Bryophyllum } \\
\text { pinnatum }\end{array}$ & Koyobtik & 0.29 & 0.29 & Leaf paste & Headache & XVIII & Topical \\
\hline Cyperaceae & $\begin{array}{l}\text { Soleria } \\
\text { scribiculata } \\
\text { Nees }\end{array}$ & Balot & 0.14 & 0.14 & Stem decoction & Boil & XIII & Oral \\
\hline Euphorbiaceae & $\begin{array}{l}\text { Euphorbia } \\
\text { hirta L. }\end{array}$ & $\begin{array}{l}\text { Tawa- } \\
\text { tawa }\end{array}$ & 0.14 & 0.14 & Leaves decoction & Fever & XVIII & Oral \\
\hline Euphorbiaceae & $\begin{array}{l}\text { Jathropa } \\
\text { curcas L. }\end{array}$ & Kuta & 0.14 & 0.43 & $\begin{array}{l}\text { Leaves or bark } \\
\text { poultice }\end{array}$ & $\begin{array}{l}\text { Fever, } \\
\text { Swelling, } \\
\text { Hematoma }\end{array}$ & XVIII & Topical \\
\hline Euphorbiaceae & $\begin{array}{l}\text { Mallotus } \\
\text { philippinensis } \\
\text { (Lam) }\end{array}$ & Banahi & 0.14 & 0.14 & Root decoction & $\begin{array}{l}\text { Gastrointestinal } \\
\text { pain }\end{array}$ & XVIII & Oral \\
\hline Gramineae & $\begin{array}{l}\text { Dimeria } \\
\text { ornithopoda } \\
\text { Trin. Fund. } \\
\text { Agrost. }\end{array}$ & Fet & 0.14 & 0.14 & Root decoction & $\begin{array}{l}\text { Pregnancy } \\
\text { related } \\
\text { condition, } \\
\text { unspecified } \\
\text { (Bughat) }\end{array}$ & XVIII & Oral \\
\hline Lamiaceae & $\begin{array}{l}\text { Hyptis } \\
\text { capitata Jacq. }\end{array}$ & $\begin{array}{l}\text { Kloan- } \\
\text { setkuda }\end{array}$ & 0.29 & 0.57 & $\begin{array}{l}\text { Leaves or root } \\
\text { decoction }\end{array}$ & $\begin{array}{l}\text { Vomiting, } \\
\text { Diarrhea }\end{array}$ & XVIII, I & Oral \\
\hline Lemnaceae & Lemna sp. & Kloansit & 0.14 & 0.14 & Root decoction & Gastic Ulcer & XI & Oral \\
\hline Malpighiaceae & $\begin{array}{l}\text { Galphimia } \\
\text { gracilis }\end{array}$ & $\begin{array}{l}\text { Kofe } \\
\text { blangul }\end{array}$ & 0.14 & 0.14 & Root decoction & Diarrhea & I & Oral \\
\hline Malvaceae & $\begin{array}{l}\text { Triumfetta } \\
\text { rhomboidea } \\
\text { Jacq. }\end{array}$ & $\begin{array}{l}\text { Stot } \\
\text { kuda }\end{array}$ & 0.14 & 0.14 & $\begin{array}{l}\text { Roots and bark } \\
\text { dabbed with } \\
\text { mineral oil }\end{array}$ & Boil & XIII & Topical \\
\hline Melastomaceae & $\begin{array}{l}\text { Melastoma } \\
\text { malabathricum } \\
\text { (Linn.) }\end{array}$ & Sumgot & 0.14 & 0.14 & $\begin{array}{l}\text { Leaf dabbed with } \\
\text { gas }\end{array}$ & Boil & XIII & Topical \\
\hline Mimosaceae & $\begin{array}{l}\text { Leucaena } \\
\text { glauca } \mathrm{L} .\end{array}$ & Ipil ipil & 0.29 & 0.29 & Fresh seeds & Ascariasis & I & Oral \\
\hline Moraceae & $\begin{array}{l}\text { Ficus } \\
\text { pseudopalma } \\
\text { Blanco }\end{array}$ & $\begin{array}{l}\text { Niyog- } \\
\text { niyogan }\end{array}$ & 0.29 & 0.29 & Bark decoction & Convulsion & XVIII & Oral \\
\hline Poaceae & $\begin{array}{l}\text { Saccharum } \\
\text { officinarum } \\
\text { Linn. }\end{array}$ & Tubo & 0.14 & 0.14 & Stem poultice & Snake bite & XIX & Topical \\
\hline Rubiaceae & $\begin{array}{l}\text { Dentella } \\
\text { repens }\end{array}$ & Byubod & 0.14 & 0.29 & Leaf paste & $\begin{array}{l}\text { Toothache, } \\
\text { Vomiting }\end{array}$ & XI, XVIII & Topical \\
\hline
\end{tabular}




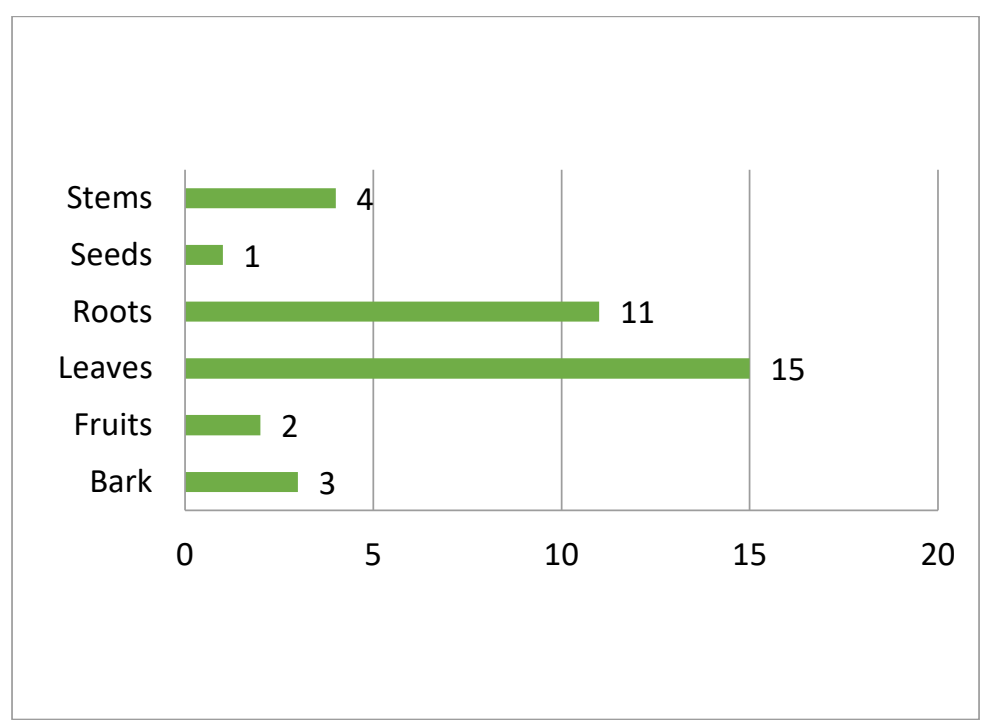

Figure 3. Ethnomedicinal Plant Parts Used.

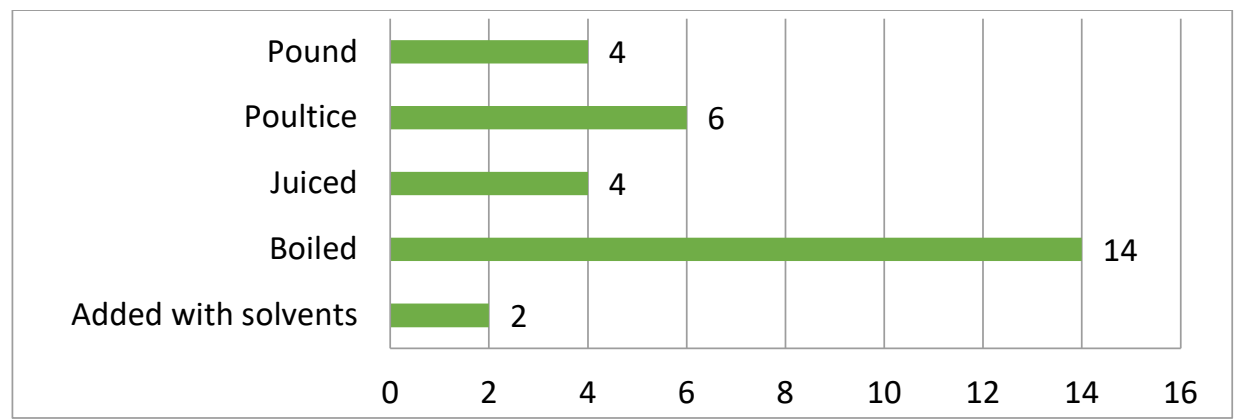

Figure 4. Ethnomedicinal Plant Preparation.

For the plant medicinal applications, most of these plants (13 spp.) were used for symptoms, signs and abnormal clinical and laboratory findings (ICD-10 Category XIII) like cough (2spp.), fever (3spp.), flatulence and related conditions (1sp.), headache (1sp), rash and other non-specific skin eruption (2spp.), nausea and vomiting (3spp.), and other and unspecified convulsion (1sp.). Plants for certain infectious and parasitic diseases (Category I) and plants for diseases of the digestive system are next in rank as shown in Table 2. Through these, we can deduce that most basis for using Tboli ethnomedicinal plants of the community is not through laboratory findings but on signs and symptoms.

Table 2. ICD-10 Categories of Ethnomedicinal Plants Applications.

\begin{tabular}{cllc}
\hline Category & \multicolumn{1}{c}{ Category Title } & \multicolumn{1}{c}{ ICD10 CODE-Cited Diseases } & $\begin{array}{c}\text { No. of Taxa } \\
\text { Used }\end{array}$ \\
\hline I & $\begin{array}{l}\text { Certain infectious and } \\
\text { parasitic diseases }\end{array}$ & $\begin{array}{l}\text { B77.9-Ascariasis, unspecified (1), AO9- } \\
\text { Diarrhea (3), BO5- Measles (1) }\end{array}$ & 5 \\
\hline \multirow{2}{*}{ IV } & $\begin{array}{l}\text { Endocrine, nutritional, and } \\
\text { metabolic diseases }\end{array}$ & F98.5-Stuttering (1) & 1 \\
\hline \multirow{2}{*}{ IX } & $\begin{array}{l}\text { Diseases of the circulatory } \\
\text { system }\end{array}$ & I10-Essential hypertension (1) & 1 \\
\hline \multirow{2}{*}{ XI } & $\begin{array}{l}\text { Diseases of the digestive } \\
\text { system }\end{array}$ & $\begin{array}{l}\text { K37-Appendicitis, unspecified (1), K08.8- } \\
\text { Other specified disorders of teeth and } \\
\text { supporting structures, Toothache (2), K25- } \\
\text { Gastric Ulcer (1) }\end{array}$ & 4 \\
\hline \multirow{2}{*}{ XII } & $\begin{array}{l}\text { Diseases of the skin and } \\
\text { subcutaneous tissue }\end{array}$ & $\begin{array}{l}\text { LO2-Cutaneous abscess, furuncle and } \\
\text { carbuncle (3) }\end{array}$ & 3 \\
\hline \multirow{2}{*}{ XIII } & $\begin{array}{l}\text { Diseases of the } \\
\text { musculoskeletal system } \\
\text { and connective tissue }\end{array}$ & $\begin{array}{l}\text { M79.8-Other specified soft tissue disorders, } \\
\text { Swelling of Legs (2) }\end{array}$ & 2 \\
\hline
\end{tabular}




\begin{tabular}{clll}
\hline $\mathbf{X V}$ & $\begin{array}{l}\text { Pregnancy, childbirth and } \\
\text { the puerperium }\end{array}$ & $\begin{array}{l}\text { O26.9-Pregnancy related condition, unspecified } \\
(2)\end{array}$ & 2 \\
\hline \multirow{2}{*}{$\mathbf{X V I I I}$} & $\begin{array}{l}\text { Symptoms, signs and } \\
\text { abnormal clinical and } \\
\text { laboratory findings, not } \\
\text { elsewhere classified }\end{array}$ & $\begin{array}{l}\text { RO5-Cough (2), R50.9-Fever (3), R14- } \\
\text { Flatulence and Related Conditions (1), R51- } \\
\text { Headache (1), R21-Rash and other non-specific } \\
\text { skin eruption (2), R11- Nausea and vomiting } \\
(3), \text { R56.8- Other and unspecified convulsion } \\
(1)\end{array}$ & 13 \\
\hline \multirow{2}{*}{$\mathbf{X I X}$} & $\begin{array}{l}\text { Injury, poisoning, and } \\
\text { certain other consequenses } \\
\text { of external causes }\end{array}$ & $\begin{array}{l}\text { T63.0- Toxic effect of contact with venomous } \\
\text { animals (1), T14.1-Open wound of unspecified } \\
\text { body region (1) }\end{array}$ & 2 \\
\hline
\end{tabular}

\section{Data on quantitative ethnomedicinal uses}

Quantitative value indices were calculated in this study to analyze the ethnomedicinal information. The highest RFC value of 0.29 described Artemisia vulgaris, Bryophyllum pinnatum, Elephantopus sp., Emilia sonchifolia, Ficus pseudopalma, Hyptis capitata, and Leucaena glauca as the most cited plants known by the informants. This corresponds to the fact that the plants were reported by highest number of informants and RFC directly depends on the number of informants mentioning use of this plants (FC) (Bano et al, 2014). As shown in Table1, E.sonchifolia has the highest Use Value $(0.71)$ followed by $H$. capitate $(0.57)$ and Jathropa curcas $(0.43)$.

The value of RFC ranges from 14 to 29 percent in the medicinal use of plants. The former is linked to 21 species of plants while the latter is linked to the seven plants mentioned above. With this, the average relative frequency citation is 18 percent. Likewise, the UV of medicinal plants ranges from 0.14 to 0.71 which shows least importance to 20 plant species to the highest importance to $E$. sonchifolia from the family Asteraceae, which corresponds with that from RFC.

\section{Phytochemical constituents of selected of ethnomedicinal plants}

Table 3 presents the results of the phytochemical screening of the ethanolic extracts of the five ethnomedicinal plants. These plants are rich in alkaloids and most are found to have flavonoids, tannins, and anthraquinones. Auwal and group [4] stated that a better therapeutic effect may be obtained from the synergy of active principles in each plant than by single isolated substance. The presence of these secondary metabolites could be highly associated with the capacity of these plants in treating various diseases. Alkaloids were detected strongly in all plant extracts as detected in both Dragendorfff's and Mayer's tests. The chemically diverse alkaloids represent a large group of plant defense compounds which are characterized by containing a nitrogen atom in a heterocyclic ring [9]. Although it is not clear why alkaloids show significant biological activity, they are often useful as drugs or biological probes for physiological studies [11]. As new and more complicated diseases are encountered worldwide, the importance of bioactive alkaloids has increased due to their potential application in chemotherapy [11]. A confirmatory test was made to screen the alkaloids found in the plants are not 'proto-alkaloid' or 'amino-alkaloid', such that these compounds lack the one or more properties of typical alkaloids. C. malorticanus and E. sonchifolia were confirmed to have primary, secondary or tertiary alkaloids. All selected plants were confirmed to have quarternary alkaloids or amine oxide. The presence of the primary, secondary, tertiary, quarternary alkaloids or amine oxides in the plant extracts are evidences that the plants are truly alkaloid-containing. Primary, secondary, tertiary, and quarternary alkaloids are classified according to the functional groups attached to the Natom of an alkaloid (e.g. primary alkaloids have $\mathrm{N}$-atom attached to a functional group while secondary alkaloids have $\mathrm{N}$-atom attached to two functional groups).

In froth test, no froth height was $>2 \mathrm{~cm}$, hence all plants are negative for saponins. Free fatty acids were observed only in E. sonchifolia and $H$. capitata. These plants if found to have low value of free fatty acid can be considered to be better quality of oil for edible use compared to those with higher value for free fatty acid as they show high risk of rancidity which if applied topologically may produce some untoward ailments such as skin-rashes, psoriasis, blisters but instead these oils can be used for medicinal purpose and also can be intake as edible materials [35]. Free fatty acids today could be used also as biomarkers [32], inducers and regulators [33]. 
Table 3. Phytochemical constituents of selected ethnomedicinal plants.

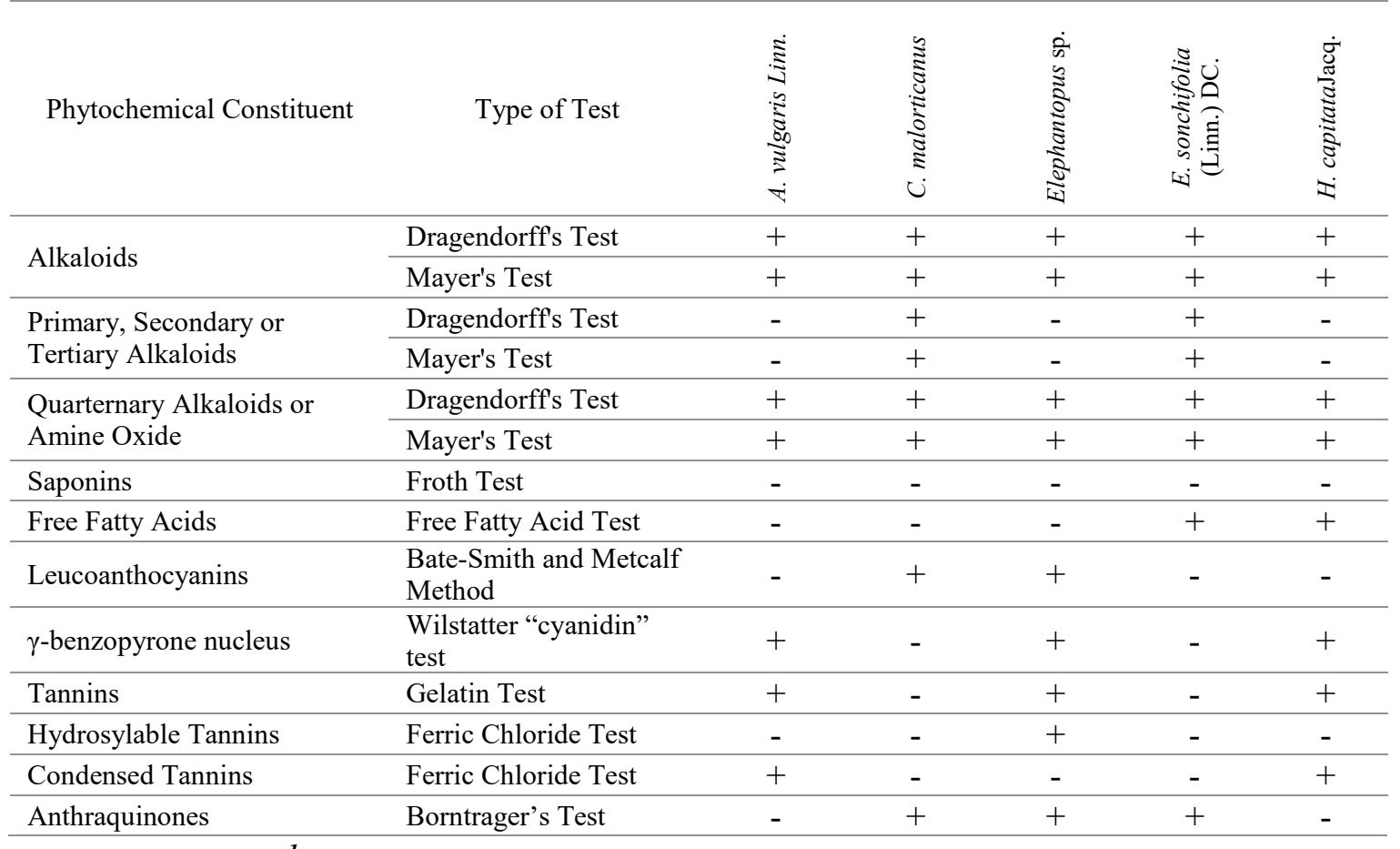

+ :present; -: absent

Leucoanthocyanins were present with $C$. malorticanus and Elephantopus sp. Leucoanthocyanins are one of the classes of flavonoids. $\gamma$-benzopyrone nucleus are present in $A$. vulgaris Linn., Elephantopus sp. and $H$. capitata. The term flavonoid is used to describe plant pigments, mostly derived from $\gamma$-benzopyrone nucleus (rings $\mathrm{A}$ and $\mathrm{C}$ in Fig. 5) [31]. Flavonoids represent a highly diverse class of secondary metabolites comprising about 9,000 structures that have been identified to date. They constitute the largest and most important group of polyphenolic compounds in plants. These compounds are found in all vascular plants as well as in some mosses [31]. Flavonoids have the ability to induce human protective enzyme systems. Flavonoids were reported to protect the gastrointestinal mucosa from lesions produced by various experimental ulcer models and against different necrotic agent [24]. In their review, Kumar and Pandey [21] found protective effects of flavonoids against many infectious (bacterial and viral diseases) and degenerative diseases such as cardiovascular diseases, cancers, and other age-related diseases.

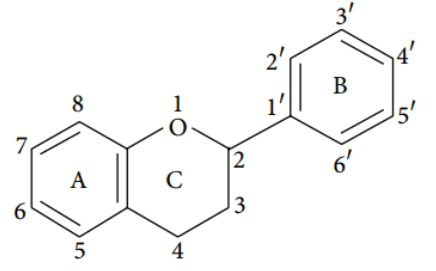

Basic flavonoid structure<smiles></smiles>

Leucoanthocyanins

Figure 5. Basic flavonoid [21] and leucoanthocyanins structure [25].

Hydrosylable tannins are found present in Elephantopus sp. and H. capitata. Condensed tannins are present in A. vulgaris and H. capitata. Tannins are polyphenolic compounds of plant origin, which are of two distinct types, hydrosylable tannins (polyesters of gallic acid and various individual sugars) and condensed tannins (polymers of flavonoids) although other tannins occur which are combinations of these two basic structures [10]. They are secondary metabolites that help defend plants against solar radiation, herbivores, and pathogens [8]. Vis-à-vis with their uses Elephantopus sp. and $H$. capitata are utilized to counteract diarrhea. Tannins are known to induce an antidiarrheal effect, these substances may precipitate proteins on the enterocytes reducing peristaltic movement and intestinal secretion [4]. 
Anthraquinones were present in C. malorticanus, Elephantopus sp. and E. sonchifolia (Linn.) DC. Anthraquinones are known as "multipotent antioxidants", as they are molecules that besides antioxidant activity possess additional pharmacological activities such as inhibition of plateletaggregation or display antineoplastic and anticancer activities [3]. Many anthraquinones also display antimicrobial, antifungal, hypotensive, analgesic, antimalarial, antileukemic, mutagenicity and antiinflammatory properties [3].

\section{Antibacterial activity of selected ethnomedicinal plants}

The ethnomedicinal plant ethanolic extracts show minimal inhibitory $(<10 \mathrm{~mm})$ activity against $S$. aureus and E. coli wherein considered to be inactive. These plants are described to have phytochemicals that could attribute for antibacterial properties, however phytochemicals in plants exist in small quantities [12] and these compounds exist in complex composition as they are in crude form. The selected plants might have nutritive or immune boosting property for being use as medicines. Such in this study, mean zone of inhibition did not exceed $10 \mathrm{~mm}$ to consider the plant extracts bioactivity as active. Ethanolic extracts of $100 \%$ concentration had higher number of zone of inhibition compared to $50 \%$ concentrations. This may be explained by the higher proportion of organic soluble constituents in $100 \%$ concentration than in $50 \%$ concentration of plant extracts. In $S$. aureus, four (4) plant extracts shows zone of inhibiton of more than $6 \mathrm{~mm}$ while in $E$. coli there were only two (2). This result is expected as Biswas and companion (2013) validated that gram negative bacteria were found to be more resistant to the plant extracts than gram positive bacteria. Gramnegative bacteria contain an outer phospholipid membrane with the structural polysaccharide components which make their cell wall impenetrable to antimicrobial agent while Gram-positive bacteria are more susceptible, having only outer peptidoglycan which is not an effective permeability barrier [13]. It was also shown that the selected ethnomedicinal plants extracts have lesser antibacterial activity compared with the standard agents, Ampicillin and Gentamycin. There was no zone of inhibition more than $6 \mathrm{~mm}$ recorded from the distilled water and the ethanol serving as negative and solvent control, respectively, which dictates that these solvents do not affect the results of the assay.

Table 4. Mean zone of inhibition $(\mathrm{mm})$ of selected ethnomedicinal plants.

\begin{tabular}{|c|c|c|c|}
\hline \multirow[b]{2}{*}{ Sample } & \multirow[b]{2}{*}{ Concentration } & S. aureus & E. coli \\
\hline & & \multicolumn{2}{|c|}{$\begin{array}{l}\text { Mean Zone of Inhibition } \\
(\mathrm{mm})\end{array}$} \\
\hline Artemisia vulgaris Linn. & $100 \% \mathrm{v} / \mathrm{v}$ & $9.7 \pm 3.1$ & $6.0 \pm 0.0$ \\
\hline Costusmalorticanus & $100 \% \mathrm{v} / \mathrm{v}$ & $8.7 \pm 3.1$ & $6.0 \pm 0.0$ \\
\hline Elephantopus sp. & $100 \% \mathrm{v} / \mathrm{v}$ & $6.0 \pm 0.0$ & $6.7 \pm 1.2$ \\
\hline Emilia sonchifolia (Linn.) DC. & $100 \% \mathrm{v} / \mathrm{v}$ & $7.7 \pm 0.9$ & $6.0 \pm 0.0$ \\
\hline HyptiscapitataJacq. & $100 \% \mathrm{v} / \mathrm{v}$ & $6.3 \pm 0.6$ & $6.0 \pm 0.0$ \\
\hline Artemisia vulgaris Linn. & $50 \% \mathrm{v} / \mathrm{v}$ & $7.3 \pm 2.3$ & $6.3 \pm 0.6$ \\
\hline Costusmalorticanus & $50 \% \mathrm{v} / \mathrm{v}$ & $6.0 \pm 0.0$ & $6.0 \pm 0.0$ \\
\hline Elephantopus sp. & $50 \% \mathrm{v} / \mathrm{v}$ & $6.0 \pm 0.0$ & $6.0 \pm 0.0$ \\
\hline Emilia sonchifolia (Linn.) DC. & $50 \% \mathrm{v} / \mathrm{v}$ & $6.0 \pm 0.0$ & $6.0 \pm 0.0$ \\
\hline HyptiscapitataJacq. & $50 \% \mathrm{v} / \mathrm{v}$ & $6.0 \pm 0.0$ & $6.0 \pm 0.0$ \\
\hline Ampicillin $^{p}$ & $1 \mu \mathrm{g} / \mu \mathrm{L}$ & $28.7 \pm 2.1$ & $16.7 \pm 2.1$ \\
\hline Gentamycin $^{\mathrm{p}}$ & $1 \mu \mathrm{g} / \mu \mathrm{L}$ & $27.7 \pm 2.1$ & $20.3 \pm 1.2$ \\
\hline Distilled Water ${ }^{\mathrm{n}}$ & $100 \%$ & $6.0 \pm 0.0$ & $6.0 \pm 0.0$ \\
\hline Ethanol $^{\mathrm{s}}$ & $100 \%$ & $6.0 \pm 0.0$ & $6.0 \pm 0.0$ \\
\hline
\end{tabular}

Zone of Inhibition, including the diameter of paper disk, p:positive control, n: negative control, s: solvent control 
Among plant extracts, the highest recorded mean zone of inhibition against $S$. aureus is $9.7 \mathrm{~mm}$ and $8.7 \mathrm{~mm}$ belonging to A. vulgaris $(100 \% \mathrm{v} / \mathrm{v})$ and E. sonchifolia $(100 \% \mathrm{v} / \mathrm{v})$, respectively. Against E. coli the highest mean zone of inhibition $(6.7 \mathrm{~mm})$ was marked by Elephantopus $\mathrm{sp} .(100 \% \mathrm{v} / \mathrm{v})$.

Among the plants used for cough, a mean zone of inhibition against $S$. aureus of $9.7 \mathrm{~mm}$ was recorded from A. vulgaris Linn. $(100 \% \mathrm{v} / \mathrm{v})$ and $8.7 \mathrm{~mm}$ was recorded from C. malorticanus $(100 \%$ v/v). However, with 50\% concentration, only A. vulgaris showed inhibition higher than $6 \mathrm{~mm} . S$. aureus causes $3-5 \%$ of community acquired pneumonia, defined as pulmonary infection including signs or symptoms of a respiratory process such as cough [20]. The said plants don't have inhibition marked against $E$. coli. With the plants used for diarrhea, only $H$. capitata showed inhibitions against $S$. aureus while Elephantopus sp. showed inhibition against E. coli. S. aureus as one the bacteria isolated from stools of children having infectious childhood diarrhea [17] while in tropical countries $E$. coli is one of the causative agents of acute diarrhea among children [18]. The plant used for vomiting, hypertension, fever, and toothache, Emilia sonchifolia, had antibacterial activity against $S$. aureus, a pyrogenic bacterium known to play a significant role in invasive skin diseases including superficial and deep follicular lesion and food poisoning [19]. These results are in accordance to the medicinal applications of these plants.

\section{Conclusions and Recommendations}

This study reports the preliminary quantitative ethnobotanical study, and the phytochemical screening and antibacterial activity of selected important ethnomedicinal plants of Tboli in Lemsnolon, Tboli, South Cotabato. Among 28 plant species belonging to 21 reported families, Asteraceae and Euphorbiaceae are the most used families in the area. The leaves were most the favored part of local users. The most treated illnesses of the Tboli tribal healers belongs into nine (9) ICD-10 categories wherein most (15spp.) are used for symptoms, signs and abnormal clinical and laboratory findings (Category XVIII) (e.g. cough, fever, flatulence, headache, rash). The most important ethnomedicinal plants known by the local community includes Artemisia vulgaris, Bryophyllum pinnatum, Dentella repens, Elephantopus sp., Emilia sonchifolia, Ficus pseudopalma, Hyptis capitata, Impatiens balsamina, Jathropa curcas, and Leucaena glauca (Fig. 6) based on their highest UV and RFC values.

The selected important ethnomedicinal plants, Artemisia vulgaris, Costus malorticanus, Elephantopus sp., Emilia sonchifolia and Hyptis capitate where found be rich in alkaloids. The alkaloids found are classified into primary, secondary, tertiary, quarternary and amine oxide alkaloids. Saponins are not present with the selected plants however some are found to have free fatty acids. Leucoanthocyanins, and $\gamma$-benzopyrone nucleus were also present in some of the selected important medicinal plants which indicates the presence of flavonoids in the respective plants. Tannins-positive plants identified through were classified unto hydrosylable and condensed tanninspositive plants. Anthraquinones were also available with some of these plants. Vis-à-vis with plant uses, the presence of these secondary metabolites supports the claims of the informants as these compounds are capable of causing varied physiochemical and pharmacological effects.

A minimal zone of inhibition considered to be inactive was recorded among the selected important ethnomediicinal plants. However, the presence of zone inhibition of plant extracts against $S$. aureus and E. coli show trends with regards to the uses of these plants. Plants used for cough, $A$. vulgaris and C. malorticanus, marked zone of inhibition against cough causing microbe, $S$. aureus. $H$. capitata and Elephantopus sp. marked zone of inhibition against $S$. aureus and E. coli, respectively, where both of these microbes are found to cause diarrhea among children. E. sonchifolia showed inhibition against pyrogenic bacteria, S. aureus. These trend support the claims of the tribal healers however the verification of this claim is far from complete. Plants antibacterial constituents might exist in small quantities or the use of these plants could be attributed to their nutritional or immune boosting property.

There is rich ethnomedicinal knowledge on the use of plants of Tboli in Lemsnolon. It is, therefore, necessary to preserve this indigenous knowledge by proper documentation, identification of plant species, and herbal preparation. Documentation of more ethnomedicinal plants and other 
ethnomedicinal resources is very likely among other Tboli communities. Conducting ethnomedicinal studies with other communities is important to cover a wider spectrum of the tribe's traditional healing practices. The phytochemical constituents of selected important ethnomedicinal plants explain the claims of the informants. These plants serves as reservoir of potential drug components. However, further phytochemical and pharmacological studies are needed to isolate the active constituents and evaluate their antimicrobial activity against a wide range of pathogens.

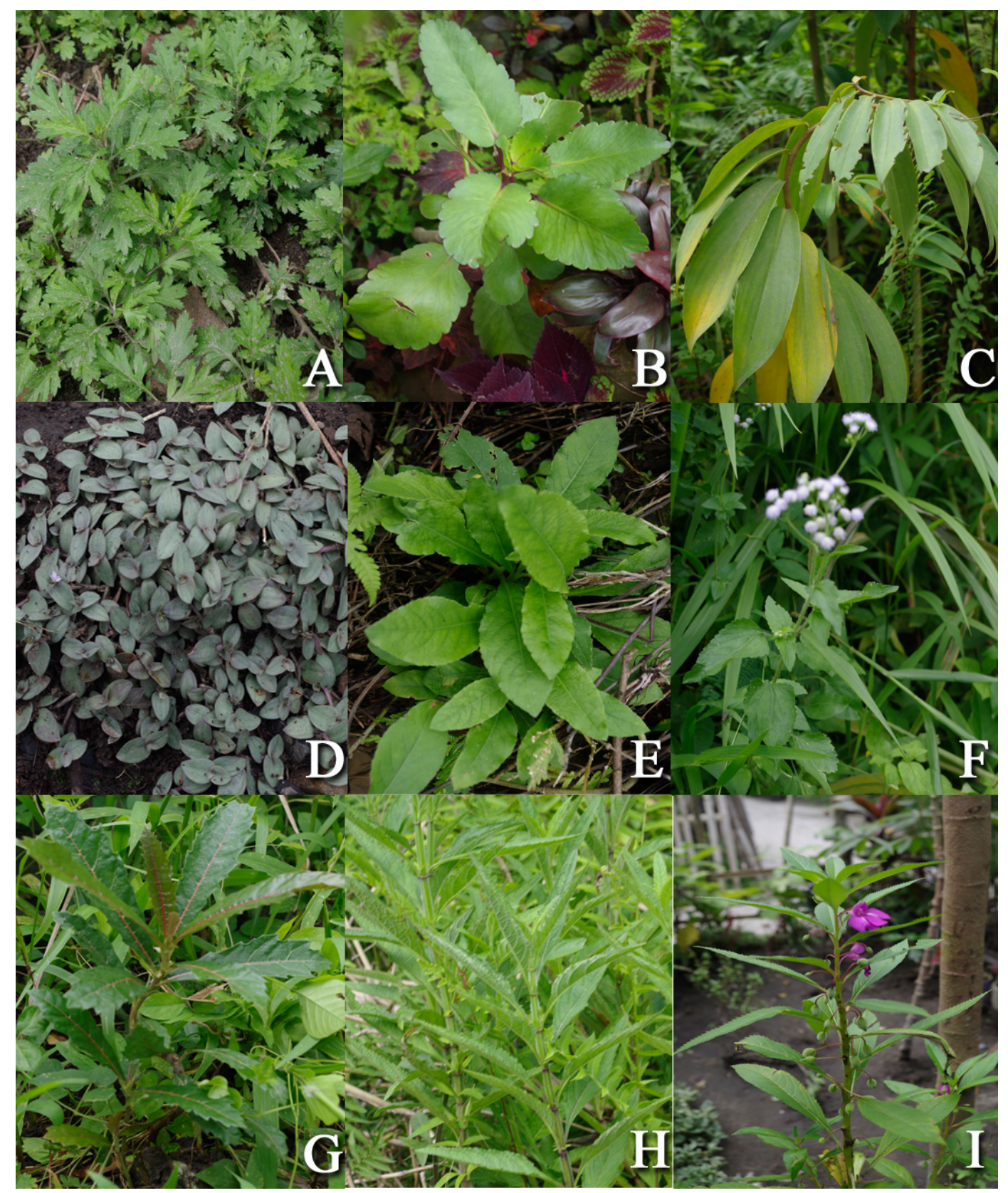

Figure 6. Selected ethomedicinal plants of T'boli in Lemsnolon, Tboli, South Cotabato. A.Artemisia vulgaris Linn., B.Bryophyllum pinnatum, C. Costus malorticanus, D.Dentella repensE.Elephantopus sp., F.Emilia sonchifolia (Linn.) DC., G.Ficus pseudopalma Blanco, H.Hyptis capitata Jacq., I.Impatiens balsamina $\mathrm{L}$.

\section{Acknowledgement}

Special thanks to Dr. Emma L. Dorado for the supervision of this study, to Mary Ann A. Otero for the support in the conduct of this study, and to Jenefa A. Sacay for coding the medicinal applications. 


\section{References}

[1] A.M. Aguinaldo et al., Phytochemistry Section in Book title "A Guide to Plant Screening: Phytochemical and Biologica" (Guevarra, ed). Research Center for Natura Sciences, University of Santo Tomas, (2005).

[2] R. Abe, K. Ohtani, An ethnobotanical study of medicinal plants and traditional therapies on Batanes Island, the Philippines. Journal of Ethnopharmacology, 145 (2013) 554-565.

[3] M.N. Akhtar et al., Total synthesis, cytotoxic effects of Damnacanthal, Nordamnacanthal and Related Anthraquinone Analogues. Molecules, 18 (2013) 10042-10055.

[4] M.S. Auwal et al., Preliminary phytochemical and elemental analysis of aqueous and fractionated pod extracts of Acacia nilotica (Thorn mimosa). Veterinary Research Forum, 5(2) (2014) 95-100.

[5] A. Bano et al., Quantitative ethnomedicinal study of plants used in the skardu valley at high altitude of Karokoram-Himalayan range, Pakistan. Journal of Ethnobiology and Ethnomedicine. 10 (2014) 43.

[6] V.D. Baddu, N.B. Ouano, Ethnobotanical Survey of Medicinal Plants Used by the Y'Apayaos of Sta. Praxedes in the Province of Cagayan, Philippines. Mindanao Journal of Science and Technology.16 (2018) 128-153.

[7] B. Biswas et al., Antimicrobial Activities of Leaf Extracts of Guava (Psidium guajava L.) on Two Gram-Negative and Gram-Positive Bacteria. International Journal of Microbiology. (2013)

[8] A.G. Calvaho et al., Tannin Adhesive from Stryphnodendron adstringens (Mart.) Coville in Plywood Panels. BioResources 9(2) (2014) 2659-2670.

[9] T.P.T. Cushnie, B. Cushnie, A.J. Lamb, Alkaloids: An overview of their antibacterial, antibiotic-enhancing and antivirulence activities. International Journal of Antimicrobial Agents, 44(5) (2014) 377-386.

[10] J. Dai, R.J. Mumper, Plant Phenolics: Extraction, Analysis and Their Antioxidant and Anticancer Properties. Pharmaceutical Sciences Faculty Publications, (2010).

[11] C.A.M. Da Rocha, Bioactive compounds from zoanthids (Cnidaria: Anthozoa): A brief review with emphasis on alkaloids. International Research Journal of Biochemistry and Bioinformatics. 3(1) (2013) 1-6.

[12] T.R. Doctor, J.F. Manuel, Phytochemical Screening of Selected Indigenous Medicinal Plants of Tublay, Benguet Province, Cordillera Administrative Region, Philippines. International Journal of Scientific and Research Publications. 4(4) (2014).

[13] A. Firas, Al-Bayati, Isolation and identification of antimicrobial compound from Mertha longifolia L. leaves grown in Iraq. Ann Clin Microbiol Antimicrob. 8 (2009) 20.

[14] R.R. Fiscal, Ethnomedicinal Plants Used by Traditional Healers in Laguna, Philippines. Asia Pacific Journal of Multidisciplinary Research. 5(4) (2017).

[15] T. Gao et al., Evaluating the feasibility of using candidate DNA barcodes in discriminating species of the large asteraceae family. BMC Evolutionary Biology. 10 (2010) 324.

[16] G.A. Gruyal, R. del Roasario, N.D. Palmes, Ethnomedicinal Plants Used by Residents in Northern Surigao del Sur, Philippines. Natural Products Chemistry \& Research, 2 (2014)4.

[17] C.I.C. Ifeanyi et al., Enteric Bacterial Pathogens Associated with Diarrhoea of Children in the Federal Capital Territory Abuja, Nigeria. New York Science Journal. 3(1) (2010). 
[18] L. Iseri et al., The prevalence of enterotoxigenic E. coli isolated from the stools of children aged 0-10 years with diarrhea in mid-anatolia region, turkey. Brazilian Journal of Microbiology, 42(1) (2011) 243.

[19] B. Joshi et al., Phytochemical extraction and antimicrobial properties of different medicinal plants: Ocimum sanctum (Tulsi), Eugenia caryophyllata (Clove), Achyranthes bidentata (Datiwan) and Azadirachta indica (Neem). Journal of Microbiology and Antimicrobials. 3(1) (2011) 1-7.

[20] A.J. Kalleen et al., Staphylococcus aureus community-onset pneumonia in patients admitted to children's hospitals during autumn and winter of 2006-2007. Epidemiology and Infection, 138(5) (2010) 666-72.

[21] S. Kumar, A.K. Pandey, Review Article: Chemistry and Biological Activities of Flavonoids: An Overview, The Scientific World Journal. 2013 (2013) Article ID 162750.

[22] G. Langenberger et al., Ethnobotanical knowledge of philippine lowland farmers and its application in agroforestry. Agroforestry Systems. 76(1) (2009) 173-194.

[23] L.M.V. Laruan et al., Phytochemical and antibacterial study of Lagerstroemia speciosa (L.) pers. And its ethnomedicinal importance to indigenous communities of Benguet Province, Philippines. Indian Journal of Traditional Knowledge. 12(3) (2013) 379-383.

[24] M.R. Laurente et al., (2017). Qualitative Phytochemical Screening of Selected Medicinal Plant Species of the Philippines. JAASP 6:1.

[25] S. Martens, A. Mithofer, Flavones and flavone synthases. Phytochemistry. 66(2005) 23992407.

[26] M. Mathur, S. Sundaramoorthy, Census of Approaches Used in Quantiative Ethbobotany. Ethno Med. 7(1) (2013) 31-58.

[27] L.G. Morilla et al., Medicinal Plants of the Subanens in Dumingag, Zamboanga del Sur, Philippines. International Conference on Food, Biological and Medical Sciences. (2014).

[28] MPDO. Municipal Planning and Development Office of Tboli, South Cotabato. Land areas and populations of Barangays in Tboli, 2017.

[29] I.C. Okeke, C.A. Ezeabara, Phytochemical screening and in vitro antimicrobial activity of various parts of Cleome ciliata Schum. \& Thonn. Bioscience Horizons: The International Journal of Student Research, 11 (2018).

[30] O. Oyebode et al., Use of traditional medicine in middle-income countries: a WHO-SAGE study. Health Policy and Planning. 31(8) (2016) 984-991.

[31] A.N. Panche, A.D. Diwan, S.R. Chandra, Flavonoids: An Overview. Journal of Nutritional Science. 5 (2016) e47.

[32] I.A. Ross et al., Free fatty acids profile of the fetal brain and the plasma, liver, brain and kidneys of pregnant rats treated with sodium arsenite at mid-organogenesis. Toxicology and Industrial Health. 26(10) (2010) 657-66.

[33] V.N. Samartsev, E.I. Marchik, L.V. Shamagulova, Free fatty acids as inducers and regulators of uncoupling of oxidative phosphorylation in liver mitochondria with participation of ADP/ATPand aspartate/glutamate-antiporter. Biochemistry, 76(2) (2011) 217-24.

[34] R. Shrivastava et al., Preliminary phytochemical screening of euphorbia thymifolia linn. Journal of Chemical, Biological and Physical Sciences (JCBPS). 3(4) (2013) 2840-2844.

[35] H.B. Soni, M. Dabhi, S. Thomas, Perspective On Phytochemical and Biochemical Compounds of Selected Indian Medicinal Plants. International Research Journal of Chemistry (IRJC) (2013) 2321-3299. 
[36] O.G. Tantengco et al., Ethnobotanical Survey of Medicinal Plants used by Ayta Communities in Dinalupihan, Bataan, Philippines. Pharmacognosy Journal. (2018)

[37] S. Vitalini et al., Traditional knowledge on medicinal and food plants used in Val San Giacomo (Sondrio, Italy)- an alpine ethnobotanical study. J. Ethnopharmacol. 145 (2013) 517-529.

[38] International Society of Ethnobiology (2006). ISE Code of Ethics (with 2008 additions). Ret rieved from http://ethnobiology.net/code-of-ethics/

[39] International Statistical Classification of Diseases and Related Health Problems $10^{\text {th }}$ Revision (ICD-10) (2010). World Health Organization. Retrieved from http://apps.who.int./classifications/icd10/browse/2010/en

[40] WHO. (2008). Traditional Medicine. WHO Fact sheet No.134. Revised. December 2008.

[41] Earth.google.com (2019). Map of Lemsnolon, Tboli, South Cotabato, Philippines. Retrieved on March 6, 2019. 